\title{
Ilmastonmuutos lämmittää Suomen kasvukausia
}

\author{
Kimmo Ruosteenoja ${ }^{1)}$, Jouni Räisänen ${ }^{2)}$, Ari Venäläinen ${ }^{1)}$ ja Matti Kämäräinen ${ }^{1)}$ \\ 1) Ilmatieteen laitos, PL 503,00101 Helsinki; kimmo.ruosteenoja@fmi.fi \\ 2) Helsingin yliopiston Fysiikan laitos
}

\section{TIIVISTELMÄ}

Ihmiskunnan tuottamien kasvihuonekaasupäästöjen vuoksi maapallon ilmasto on lämpenemässä. Lämpiäminen pidentää kasvukausia ja suurentaa kasvukauden aikana kertyvää lämpösummaa. Tässä Luonnonvarakeskuksen ja Ilmatieteen laitoksen yhteiseen Ilmapuskuri-hankkeeseen kuuluvassa tutkimuksessa on arvioitu, millaisiksi Suomen kasvukaudet muotoutuvat tulevaisuudessa. Tutkimuksen pohjana on käytetty noin 20 ilmastonmuutosmallin antamia arvioita odotettavissa olevasta lämpötilan noususta.

Ilmaston tulevat muutokset riippuvat luonnollisesti kasvihuonekaasujen päästöjen kehityksestä. Sen tähden laskelmat tehtiin erikseen kahdelle erilaiselle tulevaisuuden skenaariolle. RCP8.5skenaarion mukaan kasvihuonekaasujen päästöjen annetaan jatkaa hallitsematonta kasvuaan, jolloin lämpötila kohoaa todella voimakkaasti. RCP4.5-skenaariota luotaessa taas on oletettu, että päästöjen rajoittamisessa onnistutaan edes tyydyttävästi.

Terminen kasvukausi käsittää sen osan vuodesta, jolloin vuorokauden keskilämpötila on korkeampi kuin 5 astetta. Kasvukauden lämpösumma lasketaan vähentämällä jokaisesta kasvukauden päivän vuorokausikeskilämpötilasta viisi astetta ja ynnäämällä näin saadut lämpötilajäännökset.

Jos suurten kasvihuonekaasupäästöjen RCP8.5-skenaario toteutuisi, kasvukausi venähtäisi sadassa vuodessa noin kahdella kuukaudella. Kasvukauden lämpösumma vastaavasti suurentuisi 800-1000 astepäivällä. Etelä-Suomessa koettava kasvukausi olisi tuolloin yhtä lämmin kuin tätä nykyä Ranskassa ja Ukrainassa. Joissakin malleissa muutos toki jää pienemmäksi mutta toisissa on vielä näitäkin lukemia suurempi.

Vaikka päästöjä rajoitettaisiinkin (RCP4.5-skenaario), astepäivät lisääntyisivät noin 500:1la. Tämä toisi Etelä-Suomeen nykyistä Keski-Euroopan pohjoisosaa (Puola, Itä-Saksa) vastaavat lämpöolot.

Jo lähitulevaisuudessa suuri osa kasvukausista on olemassa olevaan kokemustietoon suhteutettuna varsin lämpimiä. Esimerkiksi 2020-luvulla enää alle $10 \%$ kasvukausista jää lämpösummaltaan jakson 1971-2000 keskiarvon alapuolelle. Vastaavasti hyvin lämpimien kasvukausien, jollaisia esiintyi 1900-luvun lopulla vain kerran 20 vuodessa, todennäköisyys olisi 2020-luvulla jo yli puolet. Viljelijät voivat hyödyntää muuttuvia olosuhteita ottamalla käyttöön entistä pidempää kasvukautta ja runsaampaa lämpöä vaativia lajikkeita. Joka vuosi ei kuitenkaan ole lämmintä, joten jonkinmoinen varovaisuus on paikallaan — ei kaikkia munia samaan koriin.

Ilmastonmuutosarvioihin liittyy kyllä vielä monia epävarmuustekijöitä. Tulokset vaihtelevat mallista toiseen, ja kuten edellä todettiin, muutoksen voimakkuus riippuu ratkaisevasti kasvihuonekaasujen tulevista päästöistä.

Avainsanat: Terminen kasvukausi, lämpösumma, tulevaisuuden ilmasto, RCP-skenaariot, ilmastonmuutosmallit 


\section{Johdanto}

Niin kauan kuin ihmiskunnan aiheuttamat päästöt jatkuvat suurina, hiilidioksidin ja muitten kasvihuonekaasujen pitoisuudet ilmakehässä nousevat nopeasti. Lisääntyvät kasvihuonekaasut nostavat maapallon keskilämpötilaa. Ilmaston lämpiäminen puolestaan pidentää kasvukausia ja suurentaa kasvukauden aikana kertyvää lämpösummaa. Hiljan ilmestyneessä Ilmatieteen laitoksen tutkimuksessa (Ruosteenoja, ym., 2015) on arvioitu, miten Suomen ja muun Euroopan kasvukaudet muuttuvat tulevaisuudessa. Laskelmat perustuvat 23 ilmastonmuutosmallin tuloksiin. Tutkimus oli osa Luonnonvarakeskuksen ja Ilmatieteen laitoksen yhteistä Ilmapuskuri-hankketta. Tässä kirjoituksissa ei käydä läpi tutkimuksessa käytettyjä laskentamenetelmiä matemaattisine kaavoineen vaan keskitytään tuloksiin.

Terminen kasvukausi käsittää sen osan vuodesta, jolloin vuorokauden keskilämpötila on korkeampi kuin $5^{\circ} \mathrm{C}$. Kasvukauden lämpösummaa laskettaessa vähennetään jokaisen kasvukauden päivän vuorokausikeskilämpötilasta viisi astetta ja lasketaan näin saadut lämpötilajäännökset yhteen. Tätä nykyä kasvukausi kestää maamme etelä- ja lounaisrannikolla keskimäärin noin puoli vuotta mutta PohjoisLapissa vain alle 4 kk. Lämpösummaa taas kertyy aivan etelässä n. 1300, Oulun korkeudella n. 1000 ja Tunturi-Lapissa 400-600 astepäivää (kuva 3).

\section{Päästöt määräävät muutoksen voimakkuuden}

Ilmastonmuutoksen voimakkuus riippuu hiilidioksidin ja muitten kasvihuonekaasujen päästöjen kehittymisestä tulevaisuudessa. Sen tähden tutkimuksessa tehtiin laskelmat erikseen kahdelle vaihtoehtoiselle kasvihuonekaasuskenaariolle. RCP8.5-skenaarion mukaan kasvihuonekaasujen päästöt kasvavat koko tämän vuosisadan ajan. Tällöin lämpötilat kohoaisivat Suomessa ennen vuosisadan loppua tarkasteltavasta ilmastomallista riippuen — talvella vähintäänkin vajaalla viidellä mutta pahimmassa

Taulukko 1. Mallitulosten perusteella lasketut Suomen alueen keskimääräiset (a) lämpötilan (asteina) ja (b) sademäärän muutokset (prosentteina). Muutokset on annettu erikseen kesälle ja talvelle, RCP4.5- ja RCP8.5skenaariolle sekä kahdelle tulevaisuuden 30-vuotisjaksolle; vertailukohtana muutoksille toimii jakson 1971-2000 keskiarvo. Keskimmäinen arvio kuvaa eri mallien tuottamien muutosten keskiarvoa. Vastaavasti sekä ala-arviota pienemmän että yläarviota suuremman muutoksen todennäköisyys on mallitulosten perusteella $5 \%$.

(a) Lämpötilan muutos $\left({ }^{\circ} \mathrm{C}\right)$

\begin{tabular}{ll|rrrr} 
& & \multicolumn{2}{|c}{ RCP45 } & \multicolumn{2}{c}{ RCP85 } \\
JAKSO & ARVIO & TALVI & KESÄ & TALVI & KESÄ \\
\hline $2040-2069$ & ALA & 1.3 & 0.9 & 2.7 & 1.4 \\
$2040-2069$ & KESKI & 3.8 & 2.3 & 5.2 & 3.1 \\
$2040-2069$ & YLÄ & 6.3 & 3.7 & 7.6 & 4.8 \\
$2070-2099$ & ALA & 2.1 & 1.2 & 4.3 & 2.4 \\
$2070-2099$ & KESKI & 4.9 & 2.9 & 7.7 & 5.0 \\
$2070-2099$ & YLÄ & 7.6 & 4.6 & 11.1 & 7.5
\end{tabular}

(b) Sademäärän muutos (\%)

\begin{tabular}{ll|rrrr} 
& & \multicolumn{2}{|c}{ RCP45 } & \multicolumn{2}{c}{ RCP85 } \\
JAKSO & ARVIO & TALVI & KESÄ & TALVI & KESÄ \\
\hline $2040-2069$ & ALA & 0 & -5 & 6 & -6 \\
$2040-2069$ & KESKI & 13 & 7 & 19 & 6 \\
$2040-2069$ & YLÄ & 25 & 18 & 32 & 19 \\
$2070-2099$ & ALA & 4 & -4 & 10 & -11 \\
$2070-2099$ & KESKI & 16 & 9 & 31 & 11 \\
$2070-2099$ & YLÄ & 29 & 21 & 51 & 32
\end{tabular}


tapauksessa noin 11 asteella (taulukko 1). Kesällä nousua olisi odotettavissa noin 3-7 astetta. Sademäärä taas kasvaisi talvella 10-50 \%, kun kesällä muutoksen ennakoidaan osuvan $10 \%$ vähentymisen ja 30 $\%$ lisäyksen muodostamaan haarukkaan.

Toiveikkaampi RCP4.5-skenaario taas olettaa, että päästöjen rajoittamisessa onnistuttaisiin vähintäänkin kohtuullisesti. Siinäkin tapauksessa lisää lämpöä olisi odotettavissa talvisin 2-7 ja kesällä $1-5$ astetta sadassa vuodessa (taulukko 1).

Vuosisadan puolivälin tienoilla (taulukossa 1 jakso 2040-2069) kaikki muutokset ovat samansuuntaisia kuin vuosisadan lopullakin mutta numeroarvoiltaan pienempiä.

Mallien ennustamista tulevista lämpötilan, sademäärän, auringon säteilyn, tuulen voimakkuuden, ym. ilmastomuuttujien muutoksista on tarjolla lisää tietoa Ilmatieteen laitoksen verkkoraporteissa (SETUKLIM, 2013a ja 2013b; Ruosteenoja, 2013).

\section{Tulevan ilmaston keskimääräinen kasvukausi}

Kuvissa 1-2 on havainnollistettu, miten terminen kasvukausi pidentyy ja lämpösumma kasvaa yhtäältä Lounais-Suomessa ja toisaalta Etelä-Lapissa. Lounaassa kasvukausi alkoi 1900-luvun lopun ilmastossa keskimäärin huhtikuun lopulla ja päättyi lokakuun puolivälissä, kun taas pohjoisessa alku ajoittui lähelle toukokuun puoltaväliä ja loppu syyskuun viimeisiin päiviin.
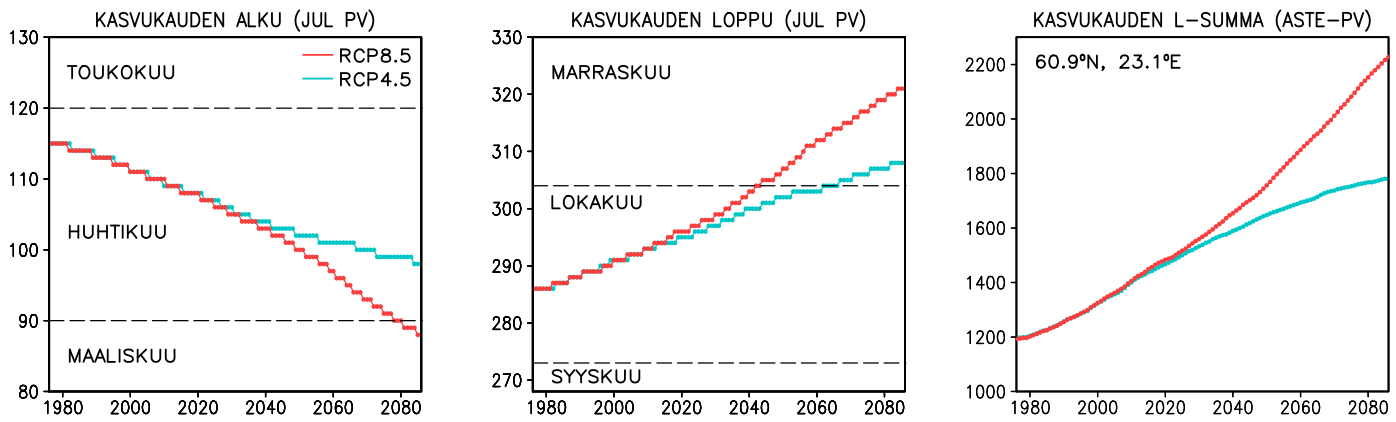

Kuva 1. Termisen kasvukauden alkamisajankohdan (vasemmalla), päättymisen (keskellä) ja lämpösumman (oikealla) ajallinen kehitys Lounais-Suomessa Loimaan tienoilla $\left(60.9^{\circ} \mathrm{N}, 23.1^{\circ} \mathrm{E}\right) 1900$-luvun lopulta 2080-luvulle; 30 vuoden liukuvia keskiarvoja. Punainen käyrä esittää nopeasti kasvavien päästöjen RCP8.5-skenaariota, sininen käyrä tasoltaan kohtuullisten päästörajoitusten RCP4.5-skenaariota. Kahdessa vasemmanpuoleisessa kuvassa numeroarvot ovat päivämääriä vuoden alusta (ns. juliaanisia päiviä). Tulkinnan helpottamiseksi näihin kuviin on merkitty kuukauden vaihtumiset katkoviivoilla; esimerkiksi lokakuun 31. päivä on vuoden alusta lukien 304. päivä.
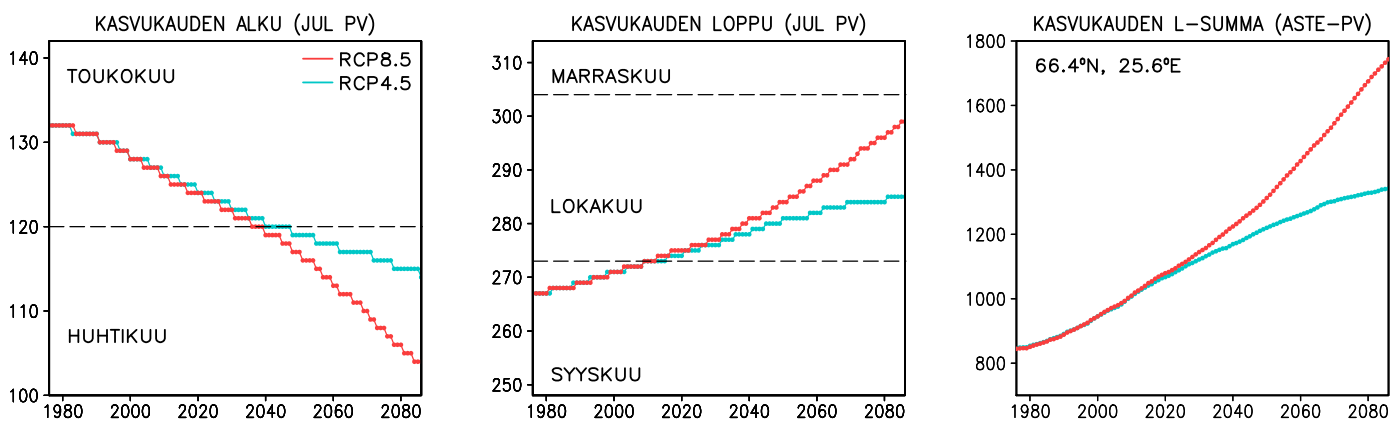

Kuva 2. Kasvukauden alkamisen (vasemmalla), päättymisen (keskellä) ja lämpösumman (oikealla) ajallinen kehitys Etelä-Lapissa Rovaniemen lähellä $\left(66.4^{\circ} \mathrm{N}, 25.6^{\circ} \mathrm{E}\right)$; ks. kuvan 1 selitystekstiä. 

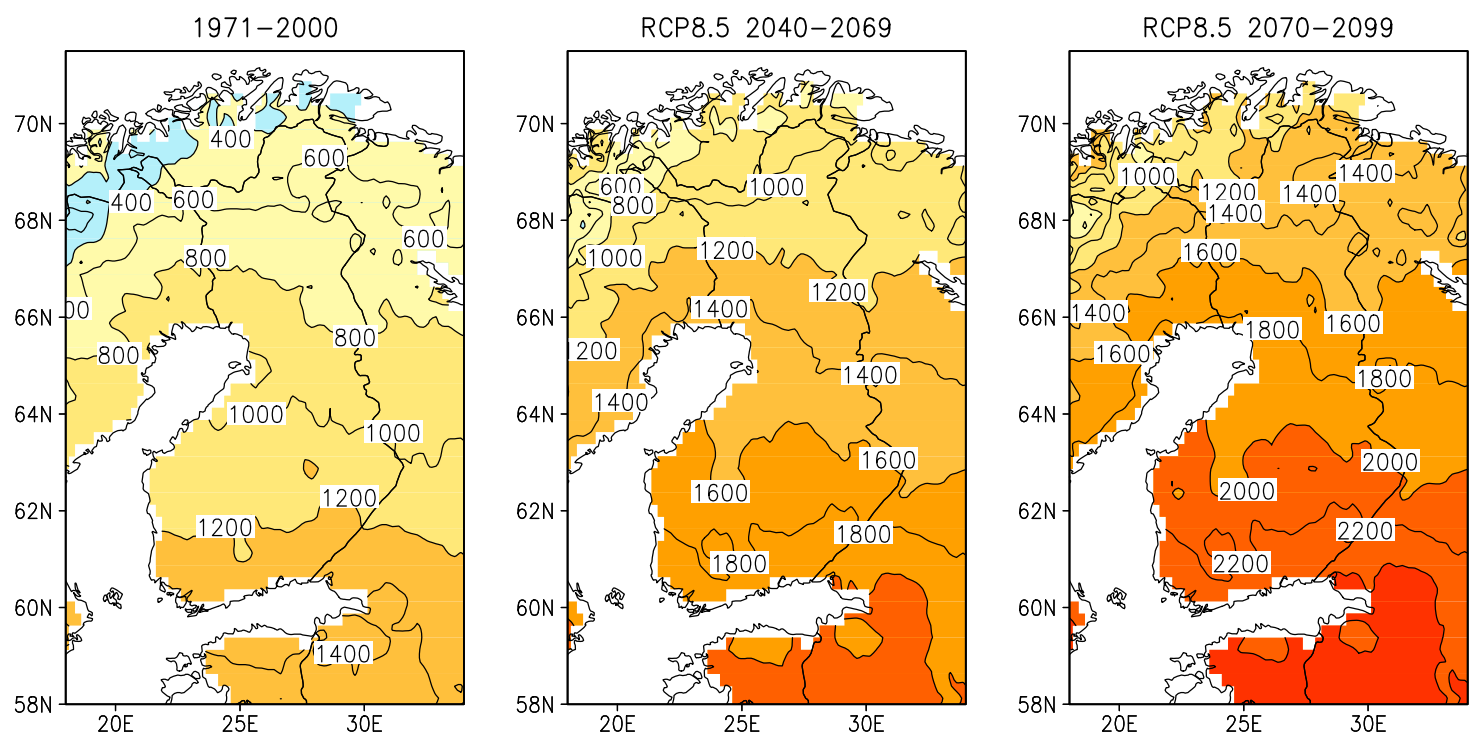

Kuva 3. Kasvukauden aikana keskimäärin kertynyt lämpösumma (astepäiviä) vuosien 1971-2000 lämpötilatietojen perusteella sekä ennustetut lämpösummat jaksoille 2040-2069 ja 2070-2099, kun on oletettu ilmastonmuutoksen etenevän hallitsemattomasti (RCP8.5-skenaario).

Suurten kasvihuonekaasupäästöjen RCP8.5-skenaarion mukaan kasvukausi pidentyisi sadan vuoden aikana noin kuukaudella molemmista päistä. Päästöjen rajoittaminen (RCP4.5-skenaario) ei juuri vaikuta muutoksen nopeuteen ennen vuotta 2040, mutta siitä eteenpäin muutoksen tahti olisi hitaampaa kuin suurten päästöjen skenaariossa. RCP4.5-skenaarionkin mukaan kasvukausi kuitenkin pidentyisi ennen vuosisadan loppua 2-3 viikolla sekä keväästä että syksystä.

Kasvukauden lämpösumma taas kasvaisi RCP8.5-skenaarion mukaan jopa 1000 astepäivällä sadassa vuodessa, RCP4.5-skenaarionkin mukaan noin 500 astepäivällä (kuvien 1-2 oikeanpuoleiset kaaviot). Myös lämpösumman kasvussa päästörajoitusten vaikutus alkaa näkyä vasta vuosisadan puoliväliä lähestyttäessä.

Kuvista 1-2 voidaan edelleen nähdä, että vuoden 2050 tienoilla terminen kasvukausi alkaa Rovaniemellä samoihin aikoihin kuin 1900-luvun lopulla Lounais-Suomessa. Myös lämpösumma on tuolloin kivunnut suunnilleen vastaaviin lukemiin. Ainakin pelkästään kasvukauden lämpöolojen perusteella voidaan siis ajatella, että Suomen vilja-aitta ulottuisi jo muutaman vuosikymmenen kuluttua aina Lapin porteille asti.

Kuvassa 3 on hahmoteltu kasvukauden lämpösummien muutoksia karttojen muodossa. Tarkasteltavan RCP8.5-skenaarion mukaan 1200 astepäivän käyrä, joka 1900-luvun lopulla kiemurteli Porin - Savonlinnan tasalla, kiipeäisi jo vuosisadan puolivälissä Keski-Lappiin. Etelä-Suomessa lämpösummaa kertyisi tuolloin 1800-2000 astepäivää, mikä vastaisi Keski-Euroopan pohjoisosien olosuhteita. Vuosisadan lopulla 1200 astepäivän lämpösummia mitattaisiin Käsivarren Lapissa. Etelä-Suomen lämpösumma taas kipuaisi 2200-2400 astepäivään, jolloin kasvukausi olisi yhtä lämmin kuin tätä nykyä Ranskassa ja Ukrainan eteläosissa. Kaikki nämä tulokset kuvaavat eri mallien antamien muutosten keskiarvoa; todellisuudessahan lämpenemisen voimakkuus toki vaihtelee aika paljon mallista toiseen, kuten taulukosta 1 voitiin nähdä.

\section{Lämpimät kasvukaudet yleistyvät nopeasti}

Edellä esitetyt arviot kuvasivat termisen kasvukauden pituuksien ja lämpösummien pitkäaikaisia keskiarvoja. Sääolot vaihtelevat tietysti vuodesta toiseen tulevaisuudessakin. Jo lähivuosikymmeninä kasvukausi on kuitenkin useimpina vuosina kokemustietoon suhteutettuna varsin lämmin. 2020-luvun 

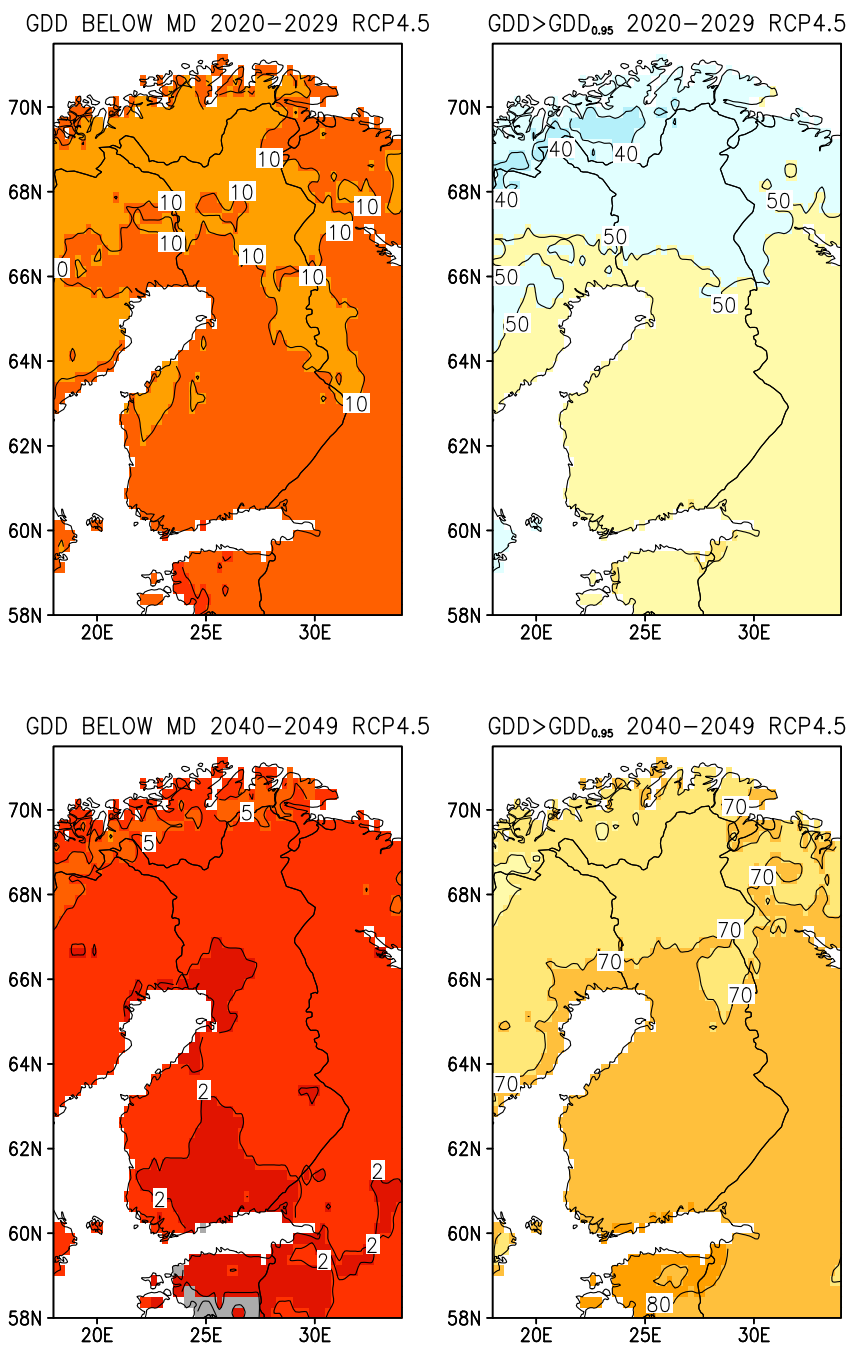

Kuva 4. Viileitten ja hyvin lämpimien kasvukausien esiintymisen todennäköisyyksiä 2020-luvulla (yläkuvat) ja 2040-luvulla (alakuvat). Vasemmalla on annettu todennäköisyydet jakson 1971-2000 keskiarvoa alhaisemman lämpösumman esiintymiselle. Oikeanpuoleiset kartat taas antavat todennäköisyyksiä hyvin korkeille lämpösummille, jollaisia esiintyi 1900-luvun lopun ilmastossa vain kerran 20 vuodessa. Arviot perustuvat RCP4.5skenaarioon, mutta vuosisadan alkupuolella eri RCP-skenaariot eivät vielä paljoa poikkea toisistaan. Alueellisiin yksityiskohtiin ei kannata kiinnittää liikaa huomiota, sillä eri mallien tuloksissa on huomattavia eroja.

tienoilla lämpösumma jää jakson 1971-2000 keskiarvon alapuolelle enää suunnilleen yhtenä kasvukautena kymmenestä (kuva 4). Hyvin lämpimien kasvukausien, jollaisia esiintyi 1900-luvun lopulla vain kerran 20 vuodessa, todennäköisyys olisi tuolloin suuressa osassa maatamme jo hieman yli puolet.

Kun ollaan edetty 2040-luvulle, 1900-luvun lopun mittapuun mukaan viileät kasvukaudet alkavat olla jo suuria harvinaisuuksia. Niitten esiintymisprosentti olisi enää vajaasta kahdesta viiteen. Vastaavasti hyvin lämpimiä kasvukausia koettaisiin jo useammin kuin kahtena vuotena kolmesta.

\section{Johtopäätöksiä}

Ilmaston lämmetessä kasvukaudetkin muuttuvat vähitellen pidemmiksi ja lämpösummat kasvavat. Muutos on oleva varsin huomattava, etenkin jos kasvihuonekaasujen päästöjen hillinnässä epäonnistutaan. Joka tapauksessa näyttää varmalta, että sellaiset kasvukaudet, jotka 1900-luvun lopun havaintotietojen perusteella luokiteltiin viileiksi, harvinaistuvat nopeasti. Jo lähivuosikymmeninä enem- 
mistö kasvukausista näyttäisi olevan tuon ajanjakson tilastoihin suhteutettuna jopa harvinaisen lämpimiä. Näin viljelijöille kertynyt kokemustieto kasvukausien "tavanomaisista" sääoloista käy vähitellen vanhaksi.

Molempien esitettyjen skenaarioitten mukaan kasvukausien muutokset etenenevät suunnilleen samaa tahtia 2030-2040-luvulle asti (kuvat 1-2). Vasta tämän jälkeen mahdolliset päästöjen rajoitukset alkavat purra, ja vuosisadan lopun ilmasto näyttää eri RCP-skenaarioissa jo hyvin erilaiselta. Toki nämä kaksi skenaariota eivät ole ainoat mahdolliset kehitysvaihtoehdot. Mitä tiukemmin päästöjä rajoitetaan, sitä pienemmiksi muutokset jäävät.

Kasvukausien lämpiämisestä on jo nähtävissä selviä viitteitä havaintotilastoista. Vuoden 2000 jälkeen lämpösummat ovat olleet Suomessa miltei kaikkina vuosina jakson 1971-2000 keskiarvojen yläpuolella. Esimerkiksi vuosina 2006, 2011 ja 2013 suuressa osassa Suomea kertyi lämpösummaa yli 300 astepäivän verran yli vertailujakson keskiarvon. Ainostaan vuonna 2008 lämpösumma jäi suurimmassa osassa Suomea selkeästi pitkäaikaista keskiarvoa alhaisemmaksi. Vuonna 2015 lämpösummat olivat koko maassa lähellä jakson 1971-2000 keskimääräisarvoja.

Kun kasvukaudet lämpenevät, Euroopan maatalouden painopiste on pikku hiljaa siirtymässä kohti pohjoista. Eteläisessä Euroopassa liiallinen kuumuus aiheuttaa lähinnä ongelmia, ja samalla vielä sateitten ennustetaan vähentyvän, varsinkin Välimeren ympäristössä (IPCC 2013, kuva 12.22; SETUKLIM 2013a, kuva 11).

Silti muutokseen sopeutuminen tuo mukanaan haasteita myös meillä. Vuosisadan lopulle ennustettuihin oloihin - hyvin korkeat kesälämpötilat ja pitkä päivä — jalostettuja viljalajikkeita ei esimerkiksi ole tarjolla. Nykyisillä lajikkeilla korkea lämpötila yhdistettynä runsaaseen valoon lyhentää jyvien muodostumisvaiheen kestoa, joilloin sato jää niukaksi (Peltonen-Sainio ym. 2009). Kasvinjalostajilla riittää siis tehtävää. Syysviljojen kasvattamista voi haitata lisäksi leutojen talvien yleistyminen. Lämpötilan heilahdellessa talvella nollan molemmin puolin satanut lumi ensin sulaa ja sitten taas jäätyy pellolle, jolloin uhkana on oraita vahingoittava jääpolte. Myös tuhohyönteiset aiheuttanevat tulevaisuudessa entistä enemmän huolta.

Lisäksi uhkatekijänä väijyy veden riittävyys. Taulukon 1 mukaan sademäärät kyllä luultavimmin kasvaisivat hieman kesälläkin, mutta korkeammissa lämpötiloissa vettä vastaavasti myös haihtuu enemmän. Lisäksi on olemassa viitteitä, että sadeolot muuttuisivat ilmaston lämmetessä aiempaa vaihtelevammiksi. Entistä yleisemmin vettä saataisiin välillä liikaa ja toisinaan taas liian vähän.

Kaiken lisäksi lämpö houkuttelee uusia luontoomme aikaisemmin kuulumattomia eläin- ja kasvilajeja asettumaan Suomeen. Samalla monet viileään ilmastoon sopeutuneet lajit uhkaavat taantua tai kadota tyyten.

On myös muistettava, että ilmastonmuutos on maailmanlaajuinen ongelma, joka koettelee erityisen kaltoin kehitysmaita. Nopean liikkuvuuden maailmassa kehitysmaitten ongelmista tulee äkkiä myös meidän ongelmiamme, mistä on esimerkkinä Eurooppaa viime aikoina koetellut siirtolais- ja pakolaisaalto. Jos ilmastonmuutoksen annetaan vapaasti edetä, eivät nämä ongelmat ainakaan helpotu, ja väkivaltaisten konfliktienkin vaara on ilmeinen. Näitten uhkakuvien rinnalla maataloutemme ilmastonmuutoksesta saamat hyödyt kalpenevat. Toki vaaratekijöistä huolimatta viljelijöitten kannattaa pyrkiä sopeutumaan edessä oleviin muutoksiin ja mahdollisuuksien mukaan hyödyntää lämpimämmän ilmaston tuomia mahdollisuuksia.

\section{Kirjallisuus}

IPCC 2013. Climate Change 2013: The physical science basis. Contribution of Working Group I to the Fifh Assessment Report of the Intergovernmental Panel on Climate Change. [T. F. Stocker, D. Qin, G-K. Plattner, M. Tignor, S. K. Allen, J. Boschung, A. Nauels, Y. Xia, V. Bex \& P. M. Midgley (toim.)]. Cambridge University Press, Cambridge, Iso Britannia. 1535 pp. <ipcc.ch>.

Peltonen-Sainio P., Jauhiainen, L., Hakala, K. \& Ojanen, H. 2009. Climate change and prolongation of growing season: changes in regional potential for field crop production in Finland. Agricultural and Food Science 18, 171-190. 
Ruosteenoja, K. 2013. Mitä uudet mallit kertovat tulevasta ilmastosta? Ilmastokatsaus 10-2013, 3-6. <ilmatieteenlaitos.fililmastokatsaus-lehti>.

Ruosteenoja, K., Räisänen, J., Venäläinen, A. \& Kämäräinen, M. 2015. Projections for the duration and degree days of the thermal growing season in Europe derived from CMIP5 model output. International Journal of Climatology. DOI: 10.1002/joc.4535.

SETUKLIM 2013a. Maailmanlaajuisiin ilmastomalleihin perustuvia lämpötila- ja sademääräskenaarioita. Verkkoraportti. <ilmatieteenlaitos.fi/setuklim>.

SETUKLIM 2013b. Ilmastomalleihin perustuvia arvioita tuulen keskimääräisen nopeuden muuttumisesta — ei selvää muutossignaalia Suomen lähialueilla. Verkkoraportti. <ilmatieteenlaitos.fi/setuklim>. 